\title{
Trends in chlorophyll-a concentration in urban water bodies within different man-used basins
}

\author{
M. Devercelli, E. Peruchet
}

Instituto Nacional de Limnología (INALI, CONICET-UNL), José Maciá 1933, Santo Tomé, Santa Fe, CP 3016, Argentina. E-mail: yomimel@yahoo.com.ar

\begin{abstract}
Chlorophyll-a concentration and physico-chemical water quality of water bodies surrounding Santa Fe City (Argentina) were analyzed at 20 sampling sites during different hydroclimatic periods (August-September 2005, March-April 2006). Areas with different water quality were separated by Euclidean cluster analysis, and correlation among both environmental and chlorophyll distance matrices were found $(\mathrm{p}<0.01)$. The areas more affected by anthropogenic influence, Los Saladillos and Salado Rivers, reached the highest trophic level as regards to chlorophyll concentration. Acceleration in the eutrophication process was registered in comparison with previous studies, and chlorophyll-a concentrations are similar to those encountered in other eutrophicated rivers of the world. The oligo-mesotrophic level found at the Setúbal shallow lake was lower than expected due to the nutrient contents and human activities of its basin. However, the incoming of pristine waters from the Paraná System produces a sweeping effect and a semi-lotic lake behavior that impedes eutrophication enhancement. During high-waters this river also improved water quality of Santa Fe and Coronda Rivers. The chlorophyll-a diminution at Setúbal Lake and Santa Fe River in comparison to earlier studies, may be also explained by the introduction in the last decade of the bivalve Limnoperna fortunei that could be responsible of important losses of algal cells. Although trophic state according to chlorophyll-a concentration was improved with discharge increments, nitrate and total phosphorus concentration augmented in most sites as a result of the input from polluted flooded areas. The higher ranges encountered in the present study either of chlorophyll-a or nutrient content, indicate changes in water quality and a resultant eutrophication process over a period of decades. The health of water bodies is not yet in danger, but it is declining due to induced man-changes.
\end{abstract}

Keywords: chlorophyll-a, eutrophication, water quality, urban water bodies

\section{Introduction}

Historically, urban settlements tend to be located near water bodies or on river alluvial valleys, since these constitute food and water source for humans. Paradoxically, as populations grow rivers are increasingly used as sewers (Walsh 2000). The magnification of extensive agriculture, municipal and industrial spilling, country and urban runoff, and ineffectively effluent treatment increase the input of organic matter and other pollutants to aquatic systems. The resulting nutrient enrichment brings about an enhancement of algal biomass, accelerating the natural eutrophication process (Harper 1992). Since the initial review of Vollenweider (1968) relating nutrient supply to lake trophic state, subsequent explorations have been done and several eutrophication indicators have been employed. Chlorophyll-a, as a proxy of phytoplankton biomass, merits its use owing to its importance in trophic relationships and ease of analysis
(OECD 1982, Dodds 2006). To constitute a good trophic level indicator, a comprehensive knowledge of aquatic system dynamics and functioning is needed, given that it is not only influenced by nutrient supply but also by other environmental factors.

Hasler (1947) summarized eutrophication symptoms in European and American lakes in relation with urban runoffs, and many other works relating nutrients and algal biomass have been published in standing waters (Dillon \& Rigler 1974, OECD 1982, Huszar et al. 2006). Despite the fact that phytoplankton in running waters is strongly modified by hydrology, turbidity and temperature, the influence of nutrient concentration is firmly entrenched (Reynolds \& Descy 1996). Rivers of urbanized areas have a long record of eutrophication attributed to anthropogenic enrichment (Carpenter et al. 1998, Dodds 2006, Duong et al. 2006). In the last decades, many Argentinean rivers have been subject to maninduced changes, and eutrophication problems have 
$1 \mathrm{a}$

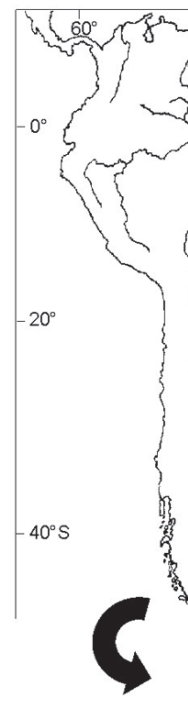

$1 b$
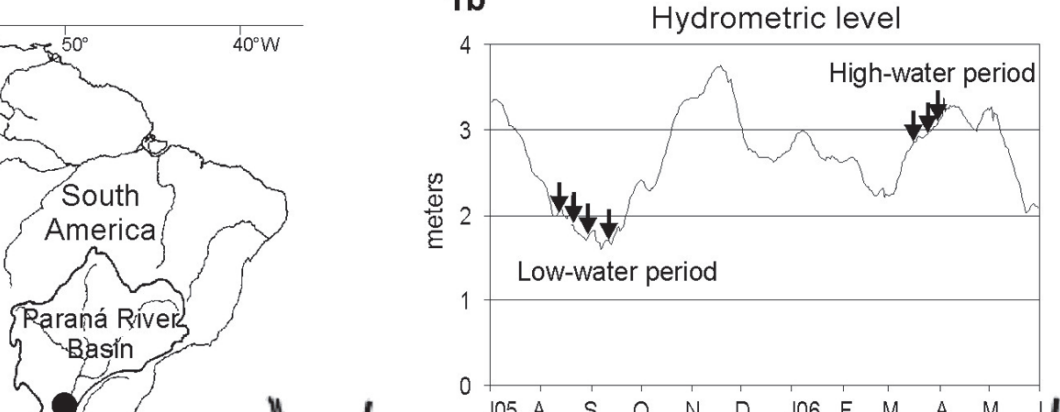

$40^{\circ} \mathrm{W}$
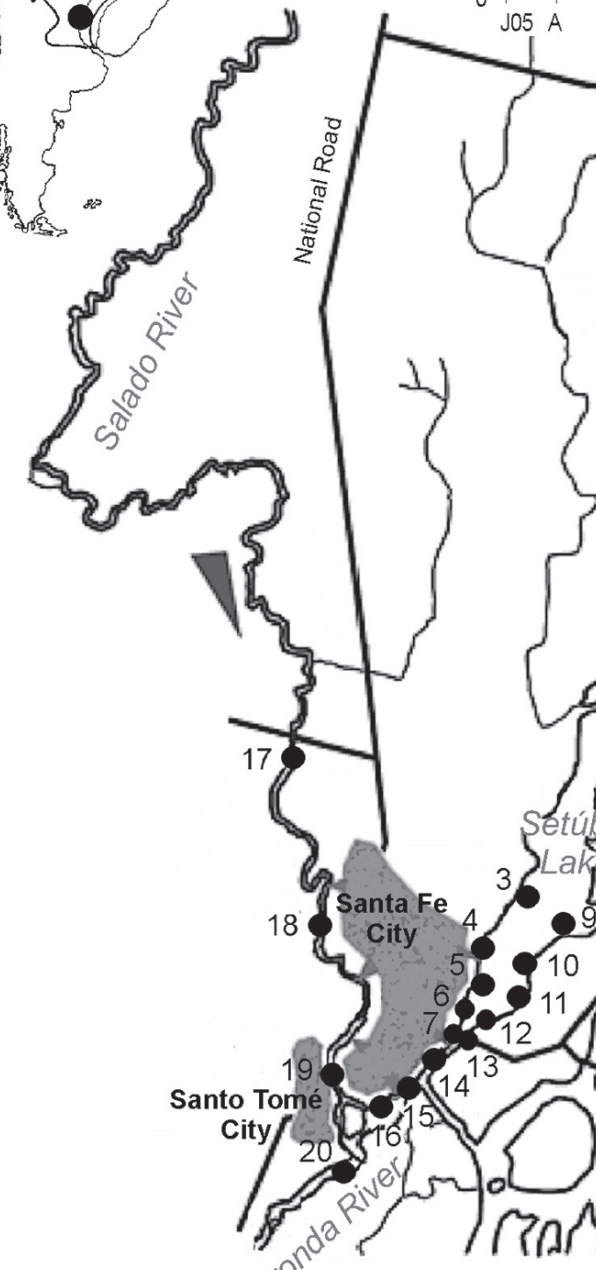

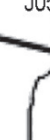
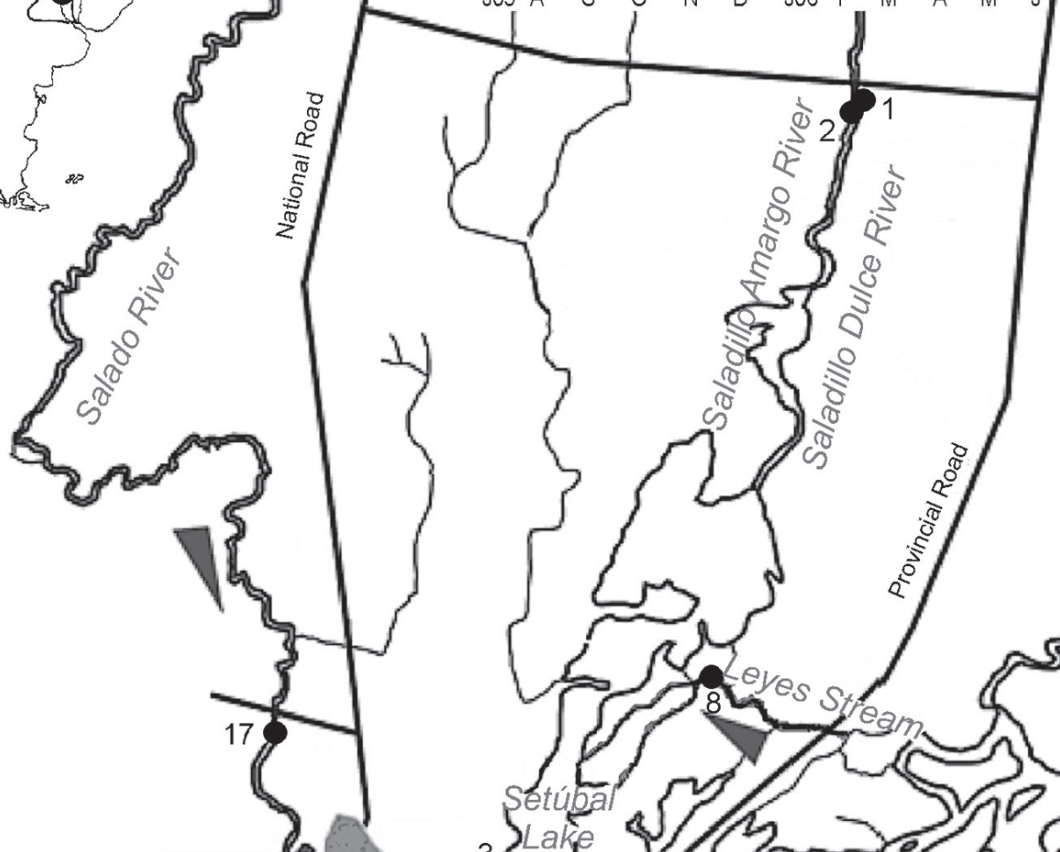

1)

Santa Fe

18

$\mathrm{Cor}^{\mathrm{O}}$

$10 \mathrm{~km}$

Fig. 1. a) Map showing the location of the sampling sites (•): Saladillo Dulce River (site 1), Saladillo Amargo River (2), Setúbal Lake right margin (3-7), Leyes Stream (8), Setúbal Lake left margin (9-13), Santa Fe River (14-16), Salado River (17-19) and Coronda River (20). b) Daily hydrometric level of the Paraná River from June 2005 to May 2006. The arrows indicate the sampling dates. 
been widespread (Gómez \& Licursi 2001, O'Farrell et al. 2002, Mercado 2003).

Santa Fe city, with approximate 451,500 inhabitants is surrounded by floodplain water bodies (Fig. 1), which are located in areas subject to different urban, industrial, agricultural and livestock development. Investigations dealing with algal biomass of Saladillo Amargo and Saladillo Dulce Rivers (García de Emiliani \& Anselmi de Manavella 1989), Setúbal Lake (Martínez de Ferrato et al. 1971), Santa Fe, Coronda (Schiaffino 1977, Perotti de Jorda 1981, Perotti de Jorda 1985) and Salado Rivers (Perotti de Jorda 1985, García de Emiliani \& Devercelli 2004) date from earlier decades. The enhancement of densely populated settlements and anthropogenic activities influencing these aquatic systems, stress the need to develop studies on water quality.

The aim of the present paper is to analyze chlorophylla changes as indicators of the water quality of aquatic systems surrounding Santa Fe City during different hydroclimatic periods. Previous studies provide a yardstick against which to measure the potential acceleration of anthropogenic eutrophication. The data obtained will be compared with the existent background information, and the anthropogenic influence will be assessed.

\section{Study area}

The Salado River is a saline turbid tributary of the ParanáRiver(Fig. 1a). It has $140 \mathrm{~m}^{3} \mathrm{~s}^{-1}$ of mean water discharge, a length of $1,500 \mathrm{~km}$ and a drainage basin of $247,000 \mathrm{~km}^{2}$ (Maglianesi \& Depetris 1970). At its lowest reach, it flows between Santa Fe and Santo Tomé Cities into Santa Fe River (a secondary channel of Paraná River) where it changes name to Coronda. It has a variable depth (3.5 to $6 \mathrm{~m}$ ) and it is fringed along its left bank by a floodplain. It receives urban, industrial and rural runoffs that are important source of organic matter. In the main channel, national swimming competitions and commercial fishing take place, and some beaches are sited for recreational use in river left margin.

The Setúbal Lake, located in the Paraná River alluvial valley, extends along the Eastern boundary of Santa Fe City. It is $35 \mathrm{~km}$ long and approximately $5 \mathrm{~m}$ depth in the centre; its width and depth are subject to the influence of the Paraná discharges through the Leyes Stream at the Northeastern end. The input of Los Saladillos System waters at the Northwestern section is less important. The lake width gradually decreases and narrows as it flows to the South ending in a strait that drains into the Santa Fe River (Bonetto \& Maglianesi 1969). This is a touristic area encompassing approximately seven beach resorts along both shores.

Saladillo Dulce and Saladillo Amargo Rivers constitute a floodplain hydrosystem (Los Saladillos) characterized by its high conductivity and salinity produced by phreatic input. Water discharge ranges from 14 to $46 \mathrm{~m}^{3}$ $\mathrm{s}^{-1}$ and drainage basin is approximates $10,700 \mathrm{~km}^{2}(280$ $\mathrm{km}$ long and $38 \mathrm{~km}$ wide). The system is bordered by land with intensive agricultural activities (García de Emiliani \& Anselmi de Manavella 1989).

\section{Material and methods}

\section{Sampling sites and laboratory analysis}

Four samplings were carried out weekly during August-September 2005 and three samplings during March-April 2006. Twenty sites were sampled in two longitudinal axis determined by Los Saladillos System Setúbal Lake - Leyes Stream - Santa Fe River, and Salado River - Coronda River (Fig. 1a). Sites were grouped in areas for their study: Los Saladillos System (sites 1 and 2), Setúbal right margin (3 to 7), Leyes Stream (8), Setúbal left margin (9 to 13), Santa Fe River (14 to 16), Salado River (17 to 19) and Coronda River (20).

Daily hydrometric level of Paraná Harbor gauge was obtained from Centro de Informaciones Meteorológicas (UNL). Water temperature (thermometer), transparency (Secchi disk depth), pH, dissolved oxygen (DO), conductivity (Hanna portable water checkers) were measured in situ. Subsurface water samples were filtered through Whatman GF/F glass-fibre filters to analyze nutrients and chlorophyll-a. Nitrate $\left(\mathrm{NO}_{3}\right)$ and total phosphorus (TP) content were lectured with spectrophotometer using chemical sets of HACHCompany. Ammonium $\left(\mathrm{NH}_{4}\right)$ was analyzed with indophenol-blue method using the Wiener chemical reactor. Biological oxygen demand $\left(\mathrm{BOD}_{5}\right)$ was determined by the dilution method after 5 days of incubation at $20^{\circ} \mathrm{C}$ (APHA 1985).

For chlorophyll-a (Chl-a) determination, 200 to 2500 $\mathrm{ml}$ of water samples were filtered. Pigments were extracted in $25 \mathrm{ml}$ of buffered acetone macerating into a glass grindex $(90 \%$ acetone $+10 \%$ distilled water) and stored at $4^{\circ} \mathrm{C}$ for $6-12 \mathrm{hs}$ in the dark. The extracts were filtered and measured with spectrophotometer at 750-664 $\mathrm{nm}$, and $665-750 \mathrm{~nm}$ after acidification with $\mathrm{HCl} 0.1 \mathrm{~N}$. The described procedure and the equation for calculating chlorophyll-a concentration are detailed in APHA (1985). 


\section{Data analysis}

Normality and homogeneity of variances were checked with Kolmogorov-Smirnov and Bartlett tests, respectively, to select the application of either parametric or non-parametric methods. Comparison between periods was performed with Student's Test with Welch correction for unequal-variance data set, or Mann Whitney test for non-normal data distributions. ANOVA with Tukey post test, or the non-parametric alternative Kruskal-Wallis with Dunn post test were used to analyze significant differences between sites (Zar 1996).

Spearman correlation coefficients were calculated to check the associations among environmental variables and among them and chlorophyll-a.

A cluster analysis based on Euclidean distance coefficient with unweighted pair group average linkage was used to identify similarities and differences among sites. Dendrograms were computed on the basis of normalized data $(\ln x+1)$ for environmental parameters $(\mathrm{pH}$, Secchi, conductivity, dissolved oxygen, nitrate, ammonium, total phosphorus and $\mathrm{BOD}_{5}$ ) and for chlorophyll-a in each period. Output from the distance matrix of environmental and chlorophyll dendrograms were used to perform Mantel test in order to check linear correlation between both in each period via 5,000 interactions $(\mathrm{p}<0.01)$.

\section{Results}

\section{Environmental conditions}

The period August to September 2005 was characterized by low-waters and temperatures (range $=11.7$ $21.5^{\circ} \mathrm{C}$ ), whereas from March to April 2006 high-waters and enhanced temperatures $\left(21.1-28.8^{\circ} \mathrm{C}\right)$ were registered ( $\mathrm{p}<0.01$, Fig. $1 \mathrm{~b})$.

Environmental parameters registered at each study area are shown in Table 1. During the low-water stage, minimum Secchi was observed at Los Saladillos System with significant differences as regards the other areas $(p<0.01$, except Leyes Stream). The highest transparency occurred at the left margin of Setúbal Lake that differed from the right one $(\mathrm{p}<0.01)$. Salado River accounted for the highest conductivity followed by Los Saladillos in comparison with the other areas $(\mathrm{p}<0.01$, Fig. 2). These systems also exhibited the most alkaline waters and their $\mathrm{pH}$ differed from those registered at Setúbal left margin and Leyes Stream $(\mathrm{p}<0.01)$. Dissolved oxygen values were near saturation. $\mathrm{BOD}_{5}$ was higher at the Salado, Coronda and Los Saladillos Rivers, whereas the Setúbal Lake achieved the lowest values $(\mathrm{p}<0.01$, Fig. 2).

Water transparency, conductivity, $\mathrm{pH}$ and dissolved oxygen concentration were inversely correlated to hydrometric level $(\mathrm{p}<0.01$, Table 2$)$. During high-water stage, transparency reduction was observed at all sites, except at Los Saladillos. Secchi was highest at the Setúbal left margin as compared to other areas $(\mathrm{p}<0.01$, except Leyes Stream). Conductivity (Fig. 2) had lower values at high-waters $(\mathrm{p}<0.01)$ except at Setúbal Lake where it increased. Salado River still showed the highest conductivity and $\mathrm{pH}$ values $(\mathrm{p}<0.01)$, followed by Los Saladillos that only differed from the Setúbal left margin and Santa Fe River $(\mathrm{p}<0.01)$. Dissolved oxygen evidenced an important reduction at all sites as regards the low-water period. $\mathrm{BOD}_{5}$ measurements (Fig. 2) were lower at Setúbal Lake and Santa Fe River, which differed from Los Saladillos, Salado and Coronda that achieved the higher values $(\mathrm{p}<0.01)$.

Nutrient concentration varied over a wide range of concentrations showing no definite pattern and several peaks at different sites throughout the study period (Table 1). Ammonium presented a marked heterogeneous distribution. Differences were only observed between the Salado River and Setúbal Lake at the lowwater period with higher values at the former $(\mathrm{p}<0.01)$. Maximum nitrate contents were measured at Coronda River with significant differences from Setúbal Lake during high-waters $(\mathrm{p}<0.01)$. Total phosphorus showed differences between both periods $(\mathrm{p}<0.01)$ and was positively correlated with water discharge $(\mathrm{p}<0.01$, Table 2$)$.

Euclidean classification analyses summarize the previous results and produces site groupings that correspond to the area distribution. At low-waters (Fig. 3) three groups were produced. Cluster GI joined high conductivity and alkaline rivers (Salado, Saladillo Dulce and Saladillo Amargo) with the lowest transparencies, and highest ammonium and phosphorus concentrations. In GII, sites located at the Setúbal right margin formed a compact group with intermediate conductivity and Secchi values. A third large cluster (GIII), defined by low conductivity and high transparency systems, included the left margin of the Setúbal Lake and Santa Fe River that were closely grouped, and Leyes and Coronda Rivers that were clustered apart.

High-waters dendrogram arrangement was similar but with sites more homogeneously distributed than at lowwaters (Fig. 3). Saladillo Dulce with lower conductivity and $\mathrm{pH}$ values joined Coronda River at GI, and was separated from Saladillo Amargo and Salado Rivers, grouped at GIV. Cluster GII was constituted by Setúbal 

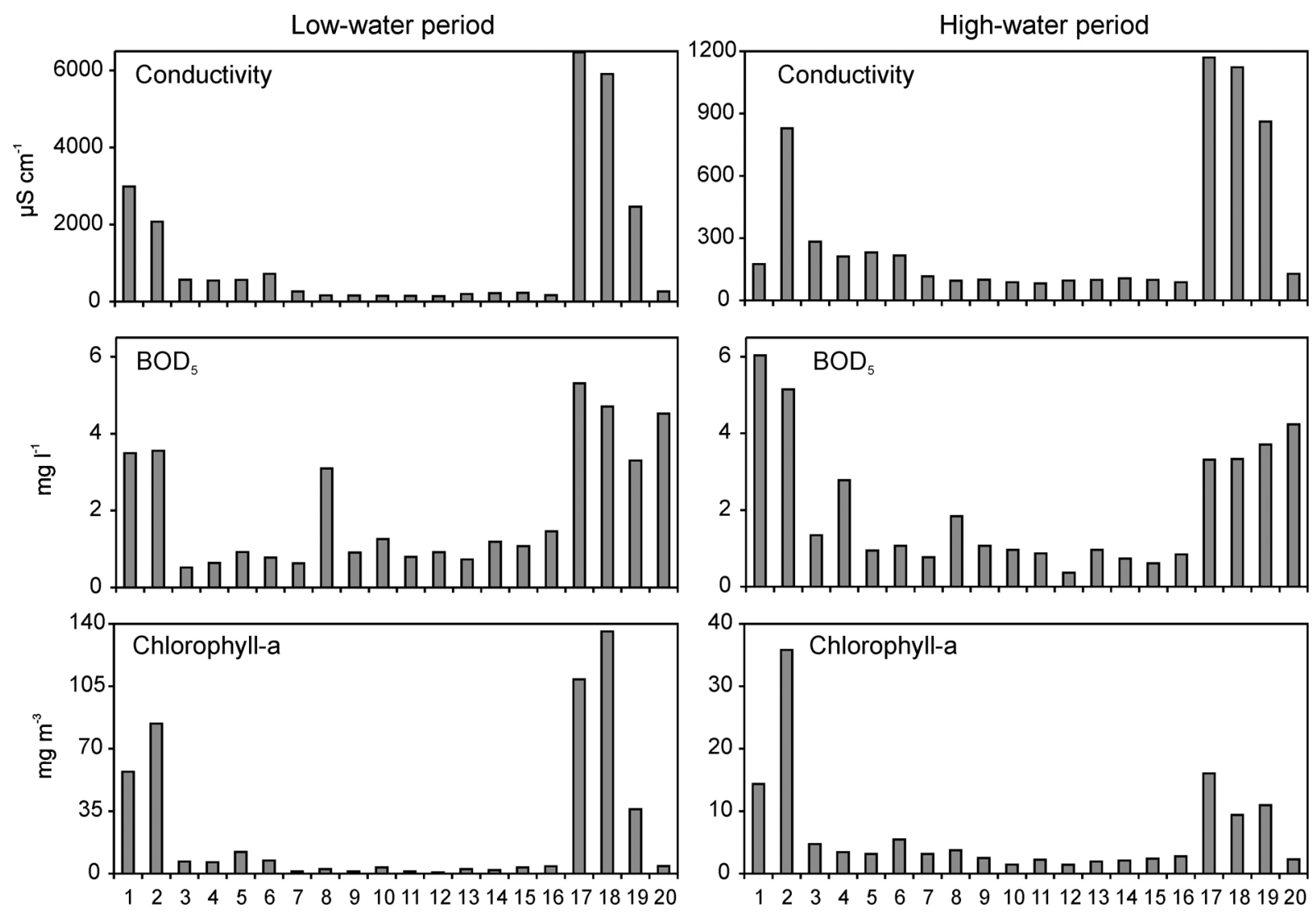

Fig. 2. Conductivity, $\mathrm{BOD}_{5}$ and chlorophyll-a variations during low-water (August-September 2005) and high-water periods (March-April 2006) at each sampling site: Saladillo Dulce River (site 1), Saladillo Amargo River (2), Setúbal Lake right margin (3-7), Leyes Stream (8), Setúbal Lake left margin (9-13), Santa Fe River (14-16), Salado River (17-19) and Coronda River (20).

right margin. The GIII comprised sites with the lower conductivity values such as Setúbal left margin, Santa Fe River and Leyes Stream clustered a little distant.

\section{Chlorophyll-a and its relation with environmental variables}

High chlorophyll-a concentration was registered during low-water discharges and it varied from 0.45 to 216 $\mathrm{mg} \mathrm{m} \mathrm{m}^{-3}$, whereas when discharge increased it ranged from 0.14 to $38 \mathrm{mg} \mathrm{m}^{-3}$. Only the Leyes Stream followed the opposite trend with pigment enhancement during high waters, and Setúbal left shore with similar values at both stages (Fig. 2). Chlorophyll-a was negatively correlated with hydrometric level at Los Saladillos System and Salado River $(\mathrm{p}<0.01 ; \mathrm{r}=-0.76$ and -0.66 , respectively), and positively correlated with Secchi at Salado River $(\mathrm{p}<0.01 ; \mathrm{r}=0.57)$. Areas with higher conductivity and $\mathrm{pH}$ coincided with maximum pigment values. Significant correlation with conductivity were found at Los
Saladillos, Salado and Setúbal right margin $(\mathrm{p}<0.01 ; \mathrm{r}=$ $0.83,0.77$ and 0.6 , respectively) and with $\mathrm{pH}$ at Los Saladillos ( $\mathrm{p}<0.01 ; \mathrm{r}=0.83)$.

The classification of sites based on chlorophyll-a data dendrogram during low-waters (Fig. 4) allowed the distinction of three groups. Los Saladillos and Salado Rivers were clustered together in GI with the highest chlorophyll-a concentration. They differed significantly from the other areas $(\mathrm{p}<0.01)$, except from the Coronda River. Saladillo Amargo registered higher concentrations than Saladillo Dulce. At GII, sites located at the Setúbal right margin formed a compact group with intermediate pigment values. Group GIII encompassed sites with lower concentrations. The Santa Fe River was linked to Leyes and Coronda Rivers, while sites located at the Setúbal left shore were clustered apart.

At high-water period (Fig. 4), groups GI and GII coincided with the previous dendrogram. Sites arranged in GI with the highest chlorophyll-a concentrations differed sig- 
Table 1. Mean values and range (in brackets) for environmental parameters and chlorophyll-a concentration in the study areas during low-water (l-w; August-September 2005) and high-water periods (h-w; March-April 2006). R= right margin; L= left margin.

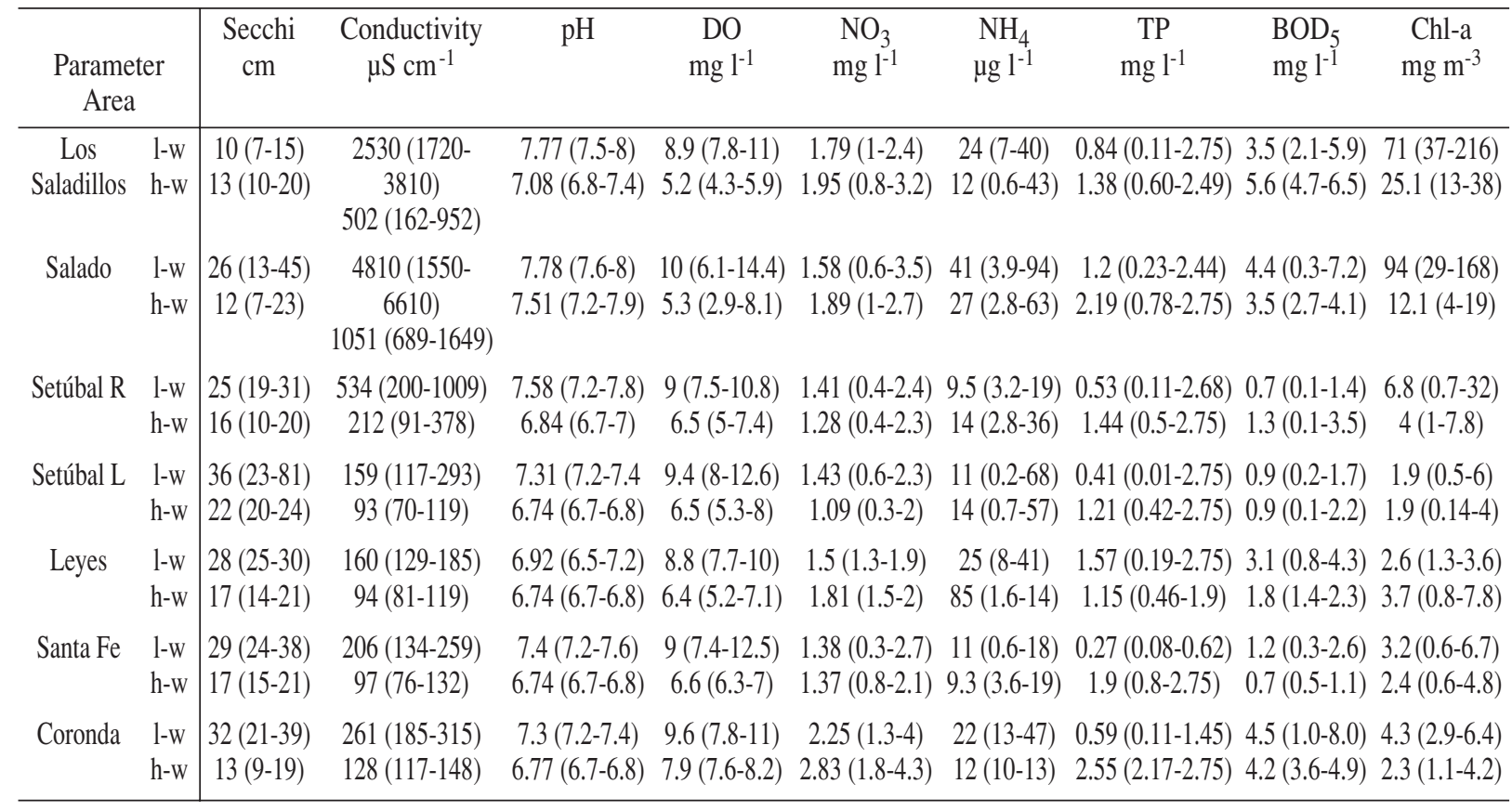

Table 2. Spearman correlation coefficient (r) among hydrometric level and environmental variables for the whole data set. $*=p<0.05$; $* *=$ $\mathrm{p}<0.01$.

\begin{tabular}{c|ccccccc}
\hline & Secchi & Conductivity & $\mathrm{pH}$ & $\mathrm{DO}$ & $\mathrm{NH}_{4}$ & $\mathrm{TP}$ & $\mathrm{BOD}_{5}$ \\
\hline Los Saladillos & & $* * \mathrm{r}=-0.81$ & $* * \mathrm{r}=-0.82$ & $* * \mathrm{r}=-0.83$ & $* * \mathrm{r}=-0.68$ & & \\
$\quad$ Salado & $* \mathrm{r}=-0.51$ & $* * \mathrm{r}=-0.81$ & & $* * \mathrm{r}=-0.58$ & $* * \mathrm{r}=-0.55$ & $* \mathrm{r}=0.55$ & $* \mathrm{r}=-0.49$ \\
Setúbal R & $* * \mathrm{r}=-0.73$ & $* * \mathrm{r}=-0.65$ & $* * \mathrm{r}=-0.88$ & $* \mathrm{r}=-0.84$ & & $* * \mathrm{r}=0.63$ & $* * \mathrm{r}=0.5$ \\
Setúbal L & $* * \mathrm{r}=-0.69$ & $* * \mathrm{r}=-0.76$ & $* * \mathrm{r}=-0.85$ & $* * \mathrm{r}=-0.83$ & & $* * \mathrm{r}=0.61$ & \\
$\quad$ Leyes & & $* * \mathrm{r}=-0.88$ & & $* \mathrm{r}=-0.83$ & & & \\
Santa Fe & $* * \mathrm{r}=-0.9$ & $* * \mathrm{r}=-0.83$ & $* * \mathrm{r}=-0.86$ & $* * \mathrm{r}=-0.89$ & & $* \mathrm{r}=0.77$ \\
Coronda & $* \mathrm{r}=-0.86$ & $* \mathrm{r}=-0.86$ & $* \mathrm{r}=-0.8$ & & & $* \mathrm{r}=0.82$ \\
\hline
\end{tabular}

nificantly from the other areas $(\mathrm{p}<0.01)$, except from the Coronda River. The SaladilloAmargo with the highest values was clustered separately from the rest of the group. Setúbal left margin, Santa Fe and Coronda Rivers were joined in GIII. A distinct isolation of Leyes Stream and the southern site of Santa Fe River were shown at GIV.

According to the Mantel test, environmental and chlorophyll-a distance matrices were strongly correlated during low- and high-water stages $(\mathrm{p}<0.01 ; \mathrm{r}=0.84$ and 0.97 , respectively).

\section{Discussion}

The different hydroclimatic periods allowed making a distinction of the systems on account of the variability of the physical and chemical parameters. Low-water stage was characterized by high mean values of Secchi, conductivity, $\mathrm{pH}$ and dissolved oxygen. Contrarily, Paraná River inputs during high-waters resulted in conductivity and $\mathrm{pH}$ diminutions associated with water dilution. Water transparency decreases mirrored the high suspended solids inputs from the turbid Paraná River (mean 


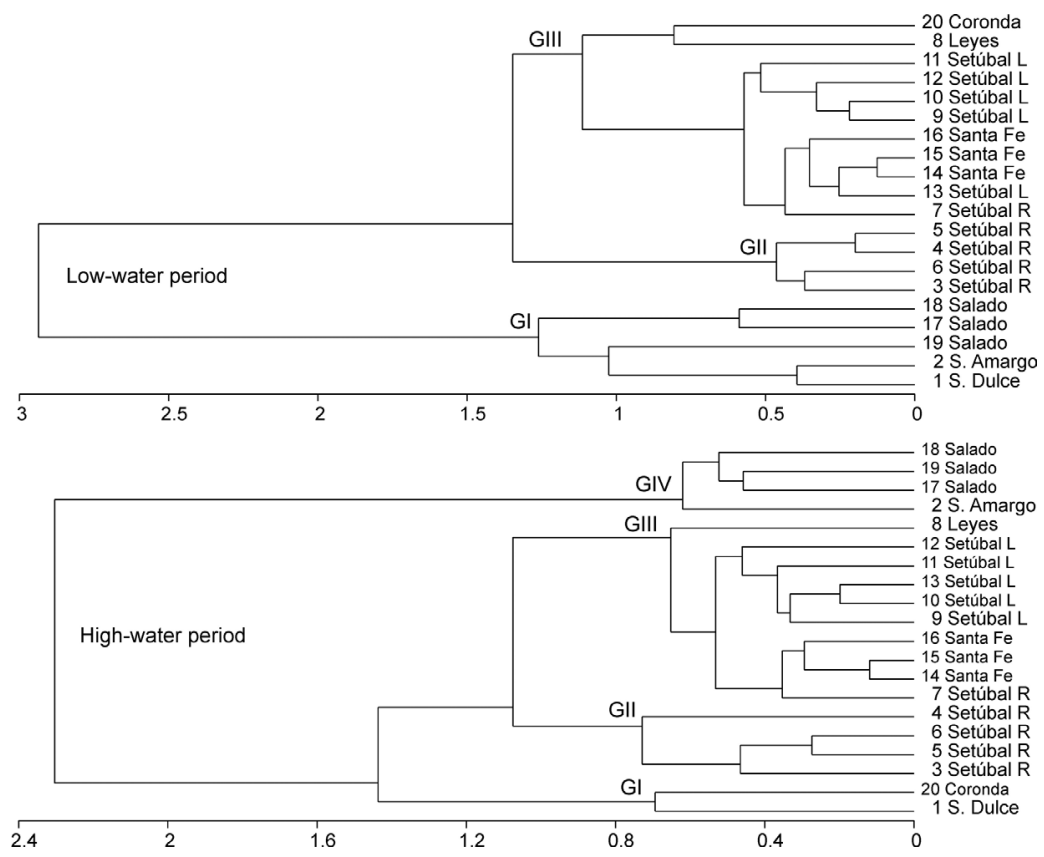

Fig. 3. Cluster analyses for 20 sampling sites on the basis of environmental variables during low-water (August-September 2005) and high-water periods (March-April 2006). The numbers are the same as in Fig. 1.

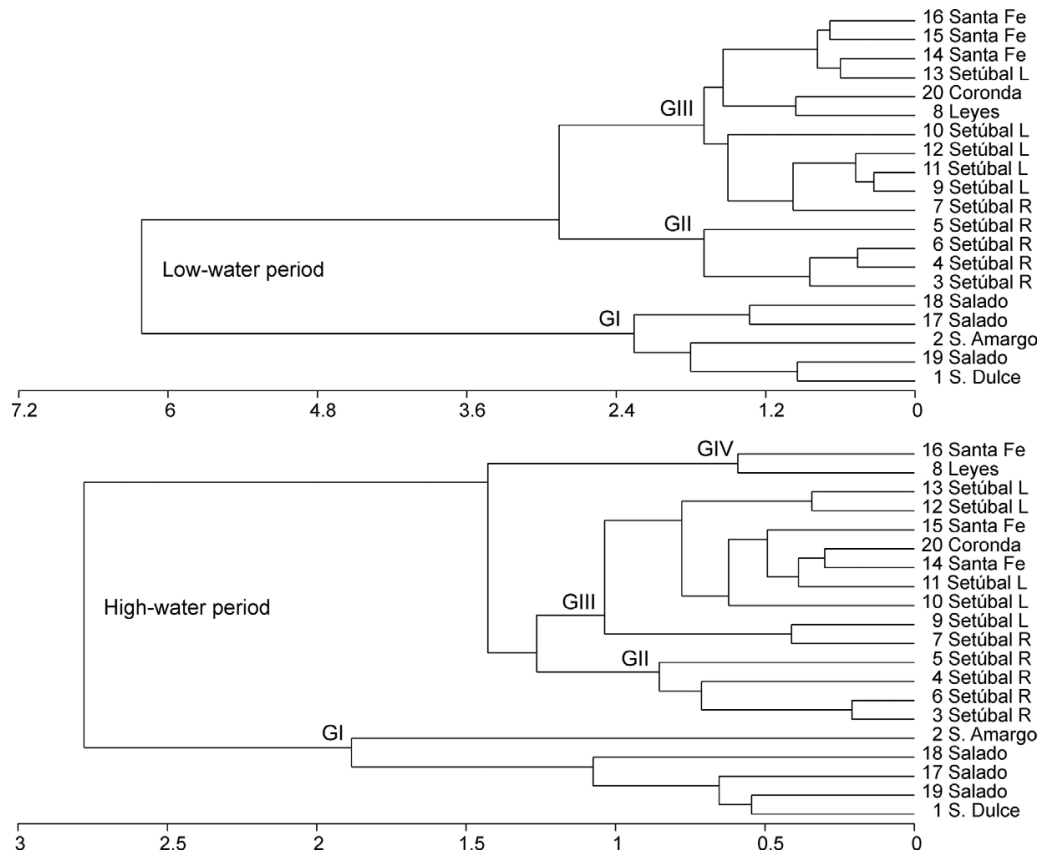

Fig. 4. Cluster analyses for 20 sampling sites on the basis of chlorophyll-a concentration during low- (August-September 2005) and high-water period (March-April 2006). The numbers are the same as in Fig. 1. 
value $276 \mathrm{mg} \mathrm{l}^{-1}$, Drago 1984), except at Los Saladillos where the lag of the flow due to inundated lateral areas augmented the sedimentation of particles (García de Emiliani \& Anselmi de Manavella 1989). Lower dissolved oxygen may be related with the incorporation of acidic and less oxygenic waters as a consequence of littoral zone inundation at the beginning of the flood (Welcomme 1992).

The nutrient concentrations measured exceeded the requirements for algal growth (Reynolds 1998). The chlorophyll component at the study sites corresponds mainly to phytoplankton, because poor light penetration $(10-30 \mathrm{~cm})$ in systems deeper than $3 \mathrm{~m}$ impedes the development of benthic algal mats usually observed in clear streams (Scheffer et al. 1993). A direct correlation between nutrient and algal biomass was not observed given the number of other factors which also influenced the development of phytoplankton. In floodplain lakes and rivers with ample nutrients and transit time enough to permit organisms reproduction, it is likely that chlorophyll production is limited by physical factors such as the hydro-sedimentological regime (Reynolds \& Descy 1996). Likewise, high enriched rivers such as the Rhine and Meuse were also found to be correlated with water discharge variations rather than with nutrient concentrations (Van den Brink et al. 1993). Nevertheless, this situation did not exclude the probability of encountering a more abundant algal biomass as rivers had great nutrient concentrations.

The study areas presented different water quality as shown in the environmental cluster analysis which revealed site groupings corresponding mainly to the conductivity and $\mathrm{pH}$ results. The significant correlation with chlorophyll dendrograms sustains the evidence of geographical differentiation. During low-waters, spatial heterogeneity was more observable given that water bodies flow in their channels preserving their own characteristics. Despite the reduction in parameters range variability and the high homogeneity among sites with water discharge increments, differences between areas still persisted.

Considering the trophic status based on chlorophyll-a concentration, limits set by Felfoldy (1987) were found to be the most adequate for classifying the study areas that belong to this floodplain. The Salado River and Los Saladillos System presented the highest trophic level, with an improvement from eutrophic to meso-eutrophic as water level increased. During low discharges, a combined effect of better light penetration caused by low suspended solid upriver input and a reduction of flowing waters constituted suitable conditions for algal develop- ment. In agreement, nutrients and $\mathrm{BOD}_{5}$ values indicated a poor water quality at both hydrological stages. The Salado River and Los Saladillos System were the areas more affected by runoff from agriculture and livestock activities. The former also receives industrial and pluvial effluents from the surrounding urban settlements. Organic pollution symptoms were pointed out previously in García de Emiliani \& Devercelli (2004) and José de Paggi \& Paggi (1998). Marchese \& Ezcurra de Drago (1999) asserted that the community structure of benthic macroinvertebrates also indicated organic pollution. The higher chlorophyll concentration, transparency and conductivity in the Saladillo Amargo as compared to the Saladillo Dulce are similar to the results of García de Emiliani \& Anselmi de Manavella (1989). They explained greatest chlorophyll by increased water retention as the floodplain broadens.

The Setúbal is a turbid shallow lake with remarkable differences between both littoral areas (Pecorari et al. 2006). The right margin is considered oligo-mesotrophic while the left is oligotrophic, maintaining the trophic levels under both hydrological conditions. The former urbanized shore receives Santa Fe City storm sewer runoffs and presented lower transparency, higher conductivity and $\mathrm{pH}$ values in accordance to the tributaries Saladillo Dulce and Saladillo Amargo water quality. At the left margin, the Paraná System discharges through the Leyes Stream, regulates the mineralization produced by the saline river inputs (Bonetto \& Maglianesi 1969). In keeping with lake nutrient concentrations and man-used basin, a higher trophic level was expected. However, the sweeping effect due to Paraná River connection limits the acceleration of the eutrophication process. In this way, the lake behaves as a semi-lotic environment with low water residence time and poor light climate that impede higher biomass production. On the other hand, in littoral patches where conditions are favorable for algal development, the growth of algae to nuisance proportions was observed especially at periods of high hydrological retentivity (Pecorari et al. 2006).

The cluster of the axis Leyes Stream-Setúbal left margin-Santa Fe River resembles a typical Paraná River section; conductivity, $\mathrm{pH}$ and chlorophyll values were similar to those found in the mainstem (Perotti de Jorda 1985). The input of the Paraná pristine discharge during high-waters improved water quality on the influenced systems. A trophic level reduction was observed on the Santa Fe and Coronda Rivers from oligo-mesotrophic to oligotrophic.

Santa Fe River transports good quality waters, but point sources of sewer effluents were evident from definite sites with worse quality (José de Paggi \& Paggi 
1998). Notwithstanding, this river recovered Coronda waters from poor quality Salado discharges that flow into it. This was also stated by Marchese \& Ezcurra de Drago (1999) in relation to changes in benthic macroinvertebrate structure.

Although trophic state according to chlorophyll-a concentration improved with increasing water discharge, nitrate and total phosphorus concentrations augmented in almost sites as a resultant of the incorporation from flooded areas. The flooding of lands affected by livestock and lakes used to retain pluvial effluents of urbanized sites, constituted a source of organic compounds to the main channels. Despite that the inverse correlation of nutrients with water discharge is the most common finding related to water dilution, such a direct correlation was also reported by García de Emiliani \& Devercelli (2004) for these systems and by Reynolds \& Descy (1996) for other rivers of the world.

The Saladillo Amargo, Saladillo Dulce and Salado Rivers achieved chlorophyll values higher than in previous reports, with concentrations comparable to those found in other eutrophicated rivers of the world (Rojo et al. 1994, Dodds 2006) or man-affected urban rivers (Moss \& Balls 1989, Van den Brink et al. 1993).

Setúbal Lake and SantaFe River had lower chlorophyll concentration but augmented nutrient content in relation to data from an earlier decade. It is hypothesized that the introduction of the bivalve Limnoperna fortunei Dunker in the plankton of the Paraná River Basin in the nineties, and specifically, the colonization of the Setúbal right margin and a stretch of the Santa Fe River, could be responsible for important losses of algal cells (Darrigan \& Ezcurra de Drago 2000). This invasive Asiatic mollusc is known to have a very high filtration rate and a reproductive phase between August-September and MarchApril in coincidence with the sampling periods. Changes in plankton abundance and structure by opportunistic filter feeders such as Dreissena and Limnoperna may be a general characteristic of man disturbed systems (Karatayev et al. 2007).

Chlorophyll concentrations of Leyes Stream, Santa Fe and Coronda Rivers are similar to those found in a stretch of the Paraná River, which is set aside of urban influence (Perotti de Jorda 1985). As regards to other world rivers, they correspond to environments with more pristine waters (Rojo et al. 1994).

The higher ranges encountered in the present study, either of chlorophyll-a or nutrient concentrations, indicate changes in water quality and a resultant eutrophication process over decades. The health of water bodies is not yet in danger, but it is declining due to the enlarge- ment of human settlement and its nuisance activities with untreated wastewater spillings. Most urbanized areas of the world have coped with eutrophication, but have not yet solve the problem. The increase in algal biomass potentially brings about severe environmental changes, including species diversity reduction, disruption of community structure and important impact to the bulk of the biota (Carpenter et al. 1998, Duong et al. 2006). The extent and emergence of eutrophication become an economic and political problem as well as a scientific one (Harper 1992). Regulatory authorities recognize the need to protect river ecosystems from this damaging process. A nutrient decrease to the aquatic systems is imperative in order to mitigate this problem. Moreover, given that the effect of enhanced nutrient contents are lessened by shorter water residence times, in well- and frequently flushed water bodies the impact of eutrophication is diminished. In this sense, it is very important to preserve the morphology and connectivity among water bodies and to avoid engineering constructions that impede the natural flowing of running waters.

\section{Acknowledgements}

The authors are indebted to the Project Director, Dr. Pablo Collins, for including them in this study. Many thanks are to colleagues for the analysis of environmental data and field assistance, to Dr. Susana José de Paggi and two anonymous referees for suggesting many improvements in the manuscript and to Dr. Inés O'Farrell for the revision of the English version. This research was supported by ANPCyT and UNL, within the framework of PICTO 2004 Project "Impacto de la ciudad de Santa Fe sobre comunidades bióticas de los hidrosistemas que la circundan".

\section{References}

APHA. 1985. - Standard Methods for the Examination of Water and Wastewater. 16th ed. American Public Health Association, Washington, $1268 \mathrm{p}$.

Bonetto A. \& Maglianesi R. 1969. - Contribución al conocimiento limnológico de la laguna Setúbal. Geomorfología, hidrología, hidroquímica y áreas bióticas. Physis, 78(29), 225-244.

Carpenter S.R., Caraco N.F. \& Correl D.L. 1998. - Nonpoint Pollution of Surface Waters with Phosphorus and Nitrogen. Ecol. Appl., 8, 559-568.

Darrigran G. \& Ezcurra de Drago I. 2000. - Distribución de Limnoperna fortunei (Dunker 1857) (Mytilidae) en la Cuenca del Plata, Región Neotropical. Medio Amb., 13, 75-79.

Dillon P. J. \& Rigler F. H. 1974. - The phosphorus-chlorophyll relationship in lakes. Limnol. Oceanogr., 19, 767-773.

Dodds W.K. 2006. Eutrophication and trophic state in rivers and streams. Limnol. Oceanogr., 51, 671-680.

Drago E. 1984. - Estudios limnológicos en una sección transversal del tramo medio del río Paraná. I: Caracteres geomorfológicos e hidrológicos. Rev. Asoc. Cs. Nat. del Litoral, 15, 1-6.

Duong T.T., Coste M., Feurtet-Mazel A., Dang D.K., Gold C., Park Y.S. \& Boudou A. 2006. - Impact of urban pollution from the Hanoi area on benthic diatom communities collected from the Red, Nhue and Tolich rivers (Vietnam). Hydrobiologia, 563, 201216. 
Felfoldy L. 1987. - Biological water classification. In L, Felfoldy (ed), Vizugyi Hidrobiologia, VGI, Budapest, 258 p.

García de Emiliani M.O. \& Anselmi de Manavella M.I. 1989. Fitoplancton y variables ambientales en al cuenca del río Saladillo (Santa Fe, Argentina). Rev. Brasil. Biol., 49, 957-967.

García de Emilinani M.O. \& Devercelli M. 2004. - Estructura y dinámica del fitoplancton de un río tributario (Salado) y cauces secundarios de río Paraná (Santa Fe, Coronda y El Vado) en el área de confluencia (Santa Fe, Argentina). Revista FABICIB, 8, 23-42.

Gómez N. \& Licursi M. 2001. - The Pampean Diatom Index (IDP) for assessment of rivers and streams in Argentina. Aquatic Ecol., 35, 173-181.

Harper D. 1992. - Eutrophication of freshwaters. Principles, problems and restoration. Chapman \& Hall, London, 327 p.

Hasler A.D. 1947. - Eutrophication of lakes by domestic drainage. Ecology, 28, 383-395.

Huszar V., Caraco N.F., Roland F. \& Cole J. 2006. - Nutrientchlorophyll relationships in tropical-subtropical lakes: do temperate models fit? Biogeochemistry, 79, 239-250.

José de Paggi S. \& Paggi J.C. 1998. - Zooplancton de ambientes acuáticos con diferentes estado trófico y salinidad. Geotrópica, 44, 95-106.

Karatayev A.Y., Boltovskoy D., Padilla D.K. \& Burlakova L.E. 2007. - The invasive bivalves Dreissena polymorpha and Limnoperna fortunei: parallels, contrasts, potential spread and invasion impacts. J. Shell. Res., 26, 205-213.

Maglianesi R. \& Depetris P. 1970. - Características químicas de las aguas del río Salado Inferior (provincia de Santa Fe, República Argentina). Physis, 30(80), 19-32.

Marchese M. \& Ezcurra de Drago I. 1999. - Use of benthic macroinvertebrates as organic pollution indicators in lotic environments of the Paraná River drainage basin. Polskie Arch. Hydrobiol., 46, 233-255.

Martínez de Ferrato A., Pérez R., Pérez Del Viso R. \& Bonnier N. 1971. - Primeros resultados de estudios sobre plancton de la laguna Setúbal (Dpto. La Capital, Santa Fe). Act. Zool. Lilloana, 28, 47-65.

Mercado L.M. 2003. - A comparative analysis of the phytoplankton from six pampean lotic systems (Buenos Aires, Argentina). Hydrobiologia, 495,103-117.

Moss B. \& Balls H. 1989. - Phytoplankton distribution in a floodplain lake and river system. II. seasonal changes in the phytoplankton communities and their control by hydrology and nutrient availability. J. Plankton Res., 11, 839-869.
O'Farrell I., Lombardo R., de Tezanos Pinto P. \& Loez C. 2002. The assessment of water quality in the Lower Luján River (Buenos Aires, Argentina): phytoplankton and algal bioassays. Envir. Poll., 120, 207-218.

OECD. 1982. - Eutrophication of Waters: Monitoring Assessment and Control. Organisation for Economic Cooperation and Development, Paris, $156 \mathrm{p}$.

Pecorari S., José de Paggi S. \& Paggi J. C. 2006. - Assessment of the urbanization effect on a lake by zooplankton. Water Res., 6(33), 677-685.

Perotti de Jorda N. 1981. - Fitoplancton del río Paraná medio (Santa $\mathrm{Fe}$, Argentina). Su variación en relación a factores ambientales en algunos cauces secundarios. Ecología , 6, 79-84.

Perotti de Jorda N. 1985. - Pigmentos del fitoplancton de ambientes lóticos del valle aluvial del río Paraná (Tramo Goya-Diamante). Physis, 43 (104), 23-29.

Reynolds, C.S. \& Descy, J.P. 1996. - The production, biomass and structure of phytoplankton in large rivers. Arch. Hydrobiol./Suppl. Large Rivers, 113(10), 161-187.

Reynolds C.S. 1998. - What factors influence the species composition of phytoplankton in lakes of different trophic status? Hydrobiologia, 369, 11-26

Rojo C., Alvarez Cobelas M. \& Arauzo M. 1994. - An elementary, structural analysis of river phytoplankton. Hydrobiologia, 289, 43-55.

Scheffer M., Hosper S.H., Meijer M.-L., Moss B. \& Jeppesen E. 1993 - Alternative equilibria in shallow lakes. TREE 8(8), 275279.

Schiaffino M. 1977. - Fitoplancton del río Paraná. I. Sus variaciones en relación al ciclo hidrológico en cauces secundarios de la llanura aluvial. Physis, 36(92), 115-125.

Van den Brink F.W.B., de Leeuw J.P.H.M., Van der Velde G., Verheggen G.M. 1993. - Impact of hydrology on the chemistry and phytoplankton development in floodplain lakes along the Lower Rhine and Meuse. Biogeochemistry, 19, 103-128.

Vollenweider R. A. 1968. - Scientific fundamentals of the eutrophication of lakes and flowing water, with particular reference to nitrogen and phosphorus as factors in eutrophication. Technical Report DC5/SC1/68.27, Organisation for Economic Cooperation and Development, Paris, $250 \mathrm{p}$.

Walsh C.J. 2000. Urban impact on the ecology of receiving waters: a framework for assessment conservation and restoration. Hydrobiologia, 431, 107-114.

Welcomme R.L. 1992. - Pesca fluvial. FAO. № 262. Roma, 303 p.

Zar J.H. 1996. - Biostatistical analysis. Prentice Hall, New York, $918 \mathrm{p}$. 

Tous droits de traduction, d'adaptation et de reproduction par tous procédés réservés pour tous pays.

La loi du 11 mars 1957, n'autorisant aux termes des alinéas 2 et 3 de l'article 41, d'une part, que les copies ou reproduction strictement réservées à l'usage privé du copiste et non destinées à une utilisation collective et, d'autre part, que les analyses et courtes citations dans un but d'exemple et d'illustration, « toute représentation ou reproduction intégrale, ou partielle, faite sans le consentement de l'auteur ou de ses ayants droits ou ayants cause, est illicite » (alinéa $1^{\text {er }}$ de l'article 40).

Cette représentation ou reproduction, par quelque procédé que ce soit, constituerait donc une contre-façon sanctionnée par les articles 425 et suivants du Code pénal.

Dépôt légal : $1^{\text {er }}$ trimestre 2008

Printed in France.

Imprimerie du Champ-de-Mars — 09700 SAVERDUN 